Southern Illinois University Carbondale

OpenSIUC

Publications

Department of Geography and Environmental

Resources

Fall 11-2015

\title{
Distinguishing between unorganized and organized convection when examining land- atmosphere relationships
}

Jessica K. Wang

University of California, Irvine, jkwang1@uci.edu

Trent Ford

Southern Illinois University Carbondale, twford@siu.edu

Steven M. Quiring

Texas A \& M University - College Station, squiring@geog.tamu.edu

Follow this and additional works at: http://opensiuc.lib.siu.edu/gers_pubs

(c) Copyright 2015 American Meteorological Society (AMS). Permission to use figures, tables, and brief excerpts from this work in scientific and educational works is hereby granted provided that the source is acknowledged. Any use of material in this work that is determined to be "fair use" under Section 107 of the U.S. Copyright Act September 2010 Page 2 or that satisfies the conditions specified in Section 108 of the U.S. Copyright Act (17 USC $\$ 108$, as revised by P.L. 94-553) does not require the AMS's permission. Republication, systematic reproduction, posting in electronic form, such as on a web site or in a searchable database, or other uses of this material, except as exempted by the above statement, requires written permission or a license from the AMS.

\section{Recommended Citation}

Wang, Jessica K., Ford, Trent and Quiring, Steven M. "Distinguishing between unorganized and organized convection when examining land-atmosphere relationships." Journal of Applied Meteorology and Climatology 54, No. 11 (Fall 2015): 2229-2243. doi:10.1175/JAMC-D-15-0086.1. 


\title{
Distinguishing between Unorganized and Organized Convection When Examining Land-Atmosphere Relationships
}

\author{
JESSICA K. WANG \\ Department of Earth System Science, University of California, Irvine, Irvine, California \\ TRENT W. FORD \\ Department of Geography and Environmental Resources, Southern Illinois University, Carbondale, Illinois \\ STEVEN M. QUIRING \\ Department of Geography, Texas A\&M University, College Station, Texas
}

(Manuscript received 24 March 2015, in final form 20 August 2015)

\begin{abstract}
In this study, the robustness of a previously developed classification system that categorizes convective thunderstorm events initiated during various synoptic and dynamic conditions is analyzed. This classification system was used to distinguish between organized and unorganized convection and then used to determine whether unorganized convection occurs preferentially over wet or dry soils. The focus is on 12 events that occurred in synoptically benign (SB) environments where the Great Plains low-level jet was not present (noLLJ), and whether these events were accurately classified as unorganized convection is evaluated. Although there is a small sample size, the results show that the classification system fails to differentiate between local unorganized convection and large-scale organized convection under SB-noLLJ conditions. The authors conclude that past studies that have used this classification to study how soil moisture influences unorganized convection should be revisited. Additional variables and/or alternative precipitation datasets should be employed to enhance the robustness of the classification system.
\end{abstract}

\section{Introduction}

Soil moisture influences latent and sensible heat fluxes and moisture partitioning and modulates relationships between the land surface and atmosphere (Entin et al. 2000; Legates et al. 2011). The persistence of soil moisture affects long-term atmospheric conditions and influences the climate on monthly to seasonal time scales. Anomalously low soil moisture limits the amount of water available for evaporation (Karl 1986; Delworth and Manabe 1988; Wang and Kumar 1998; Mostovoy and Anantharaj 2008), which suggests precipitation may occur preferentially over wetter soils (Dirmeyer et al. 2000). The degree of soil moisture persistence (i.e., soil moisture memory) varies by region, and in the central United

Correspondence author address: Jessica Wang, Dept. of Earth System Science, University of California, Irvine, 3200 Croul Hall, Irvine, CA 92697.

E-mail: jessica.km.wang@gmail.com
States it has been shown to range from 1 to 3 months (Robock et al. 2000; Entin et al. 2000). However, it is still unclear whether variations in synoptic and dynamic conditions influence how soil moisture impacts the initiation and location of precipitation. This study evaluates the robustness of a previously developed classification system that identifies organized and unorganized convective precipitation events to clarify under which conditions these precipitation events are more favorable.

Most soil moisture-precipitation coupling studies are based on models, and relatively few studies have used in situ soil moisture measurements to examine these relationships. Ford et al. (2015, hereinafter referred to as FRQ15) investigated the likelihood of afternoon precipitation occurring over wet or dry soils in Oklahoma using in situ soil moisture measurements. They concluded that precipitation occurred preferentially over wet soils when atmospheric conditions were unfavorable for convection and the Great Plains low-level jet (LLJ) was not 
present. The synoptic-dynamic classification system that FRQ15 used was adopted from Frye and Mote (2010). It separates unorganized convective activity forced by surface flux/heating anomalies from more organized convection that initiated by mechanical lifting associated with the passage of fronts and low pressure systems. In contrast, Taylor et al. (2012) demonstrated that convective precipitation occurred preferentially over drier soils in many regions of the world. Dry soils were associated with larger sensible heat fluxes, which destabilized the atmosphere and increased the likelihood for convective precipitation.

Multiple studies have explored soil moisture and precipitation feedbacks (e.g., Carleton et al. 2008; Alfieri et al. 2008; Allard and Carleton 2010; Mei and Wang 2011), but the implicit connection between soil moisture and precipitation makes it difficult to quantify the relationship. Soil moisture influences the local latent and sensible heat fluxes, moisture convergence, and atmospheric circulation (Pielke 2001; Gu et al. 2006; Wei and Dirmeyer 2012; Ek and Holtslag 2004; Koster and Suarez 2004), and these can influence convective precipitation (Taylor et al. 2007; Jones and Brunsell 2009). Taylor and Ellis (2006) found that strong gradients of sensible heat, caused by soil moisture gradients, were more likely to result in mesoscale convection over dry soils rather than wet soils. In addition, the Bowen ratio (the ratio of sensible heat to latent heat fluxes) is a function of surface wetness, and small (large) ratios represent moist (dry) surface conditions. Rabin et al. (1990) suggested that clouds form earlier over areas characterized by high sensible heat flux (high Bowen ratio). On the other hand, clouds are suppressed over areas characterized by high latent heat flux (low Bowen ratio), implying that convective initiation may occur preferentially over drier soils.

The purpose of this study is to evaluate the robustness of the classification system presented in FRQ15. Specifically, we are interested in determining whether the events that FRQ15 identified during synoptically benign (SB) conditions when the LLJ was absent (noLLJ) were classified correctly. This is important because these atmospheric conditions (SB-noLLJ) are hypothesized as soil moisture conditions that may have a greater influence on where/if precipitation occurs. That is, if the synoptic-scale atmospheric conditions are less conducive to convective initiation, local land-atmosphere interactions due to soil moisture may be of greater importance. We validate the classification employed by FRQ15 using two different approaches: 1) analysis of all convective events and 2) analysis of convective events that occur only in SB environments with no LLJ. We selected two SB-noLLJ events (one event associated with dry soil conditions and one event associated with wet soil conditions) for a more detailed case study analysis. The antecedent atmospheric and soil moisture conditions associated with these convective events are examined. Using a case study approach, we can better detail fluxes of moisture and energy from the land surface and investigate whether the presence (or absence) of soil moisture impacts convective precipitation.

One limitation of this study is the small sample size. The results may not be representative of all convective precipitation events. However, this study contributes to our understanding of land-atmosphere interactions by evaluating the robustness of a classification system that has previously been used to isolate how soil moisture influences convective precipitation events. This will further help identify how future event-based studies should be conducted. The classification system and criteria are described in section 2. The results of the composite analysis and two case studies are presented in section 3 . This is followed by discussion (section 4 ) and conclusions (section 5).

\section{Data and methods}

\section{a. Synoptic environment}

We utilize the methods of FRQ15, which were adopted from Frye and Mote (2010), to classify afternoon convective events into four categories based on synoptic and dynamic conditions. FRQ15 used this approach to identify convective precipitation events and exclude stratiform precipitation events. They identified 353 convective precipitation events in Oklahoma from 2003 to 2012 based on the synoptic conditions. The classification system uses a modified convective trigger potential (CTP; Findell and Eltahir 2003), similar to the observed lapse rate. The modified CTP is used to characterize the overall atmospheric stability prior to event initiation. Daily 1200 UTC atmospheric sounding temperature profiles from five stations (Amarillo, Texas; Fort Worth, Texas; Norman, Oklahoma; Lamont, Oklahoma; and Dodge City, Kansas) determined the stability of the synoptic-scale atmosphere for the individual events. The modified CTP is calculated based on the lapse rate of the sounding between 850 and $700 \mathrm{hPa}$. Following the method from Frye and Mote (2010), if the lapse rate was less than $6.0^{\circ} \mathrm{C} \mathrm{km}^{-1}$, the atmosphere was considered to be synoptically benign. If the lapse rate was greater than or equal to $6.0^{\circ} \mathrm{C} \mathrm{km}^{-1}$, the synoptic environment was classified to be unstable or synoptically primed (SP). If two of the five stations exhibited an SP environment, the synoptic conditions would be classified as SP.

In addition to the modified CTP, the classification system used by FRQ15 considers the Great Plains LLJ for 
identifying precipitation events. The LLJ is a fast-moving band of air that causes a northward advection of warm, moist air from the Gulf of Mexico in the lower levels of the atmosphere (Bonner 1968). The influx of moisture provided by the LLJ can decrease the stability of the lower atmosphere and cause conditions to be favorable for convective precipitation in the Great Plains (Higgins et al. 1997; Wu and Raman 1998). The presence of the LLJ was identified using daily 1200 UTC winds at the 850-hPa level from the North American Regional Reanalysis (NARR; Mesinger et al. 2006) dataset. The NARR dataset provides atmospheric and hydrological variables eight times in 3-h intervals from 1979 to present at a $32-\mathrm{km}$ resolution over the northern Lambert conformal conic grid. If vector winds from the Gulf of Mexico (i.e., southerly or southeasterly winds) were greater than $12 \mathrm{~m} \mathrm{~s}^{-1}$ in more than $75 \%$ of the grid cells, both Frye and Mote (2010) and FRQ15 concluded that the LLJ was present. The four categories within the classification system are SP-LLJ, SB-LLJ, SP-noLLJ, and SB-noLLJ.

\section{b. Soil moisture data}

Soil moisture data were obtained from the Oklahoma Mesonet (http://www.mesonet.org; Illston et al. 2008). Volumetric water content of the soil was estimated using the thermal matric potential, measured by a Campbell 229-L heat dissipation sensor. Soil measurements taken from $5 \mathrm{~cm}$ at 0600 UTC were used in this study. The station-based soil moisture measurements were converted into a $1 / 4^{\circ}$ grid spacing dataset using the mean of all stations in each grid cell. Over the entire study region (431 grid cells), 113 cells have at least one mesonet site. Soil moisture percentiles were calculated using the empirical cumulative distribution function from all volumetric water content measurements in a given calendar month. The percentiles are a standardized measurement of soil water content compared with the entire period of record. A percentile value of 1 represents the maximum soil water content $(100 \%), 0.5$ represents the median soil water content $(50 \%)$, and 0 is the minimum soil water content $(0 \%)$. Soil moisture percentiles were used instead of volumetric water content because they facilitate comparisons across Oklahoma irrespective of variations in soil characteristics and climate.

\section{c. CMORPH precipitation events}

FRQ15 identified over 1600 convective precipitation events by using the Climate Prediction Center morphing technique (CMORPH; Joyce et al. 2004) during the warm season (May-September) from 2003 to 2012. CMORPH combines data from passive microwave sensor satellites with thermal-infrared data from geostationary satellite data at a $14^{\circ}$ grid spacing. Following the methods of Taylor et al. (2012), the grid point with the maximum precipitation accumulation during an event is selected as the location of that specific event's convective precipitation. The grid point is then matched with the corresponding in situ soil moisture value. Of the 1600 events, FRQ15 found that 353 of these events occurred in locations with available soil moisture observations (i.e., occurred within a grid cell with soil moisture data). Fifty-six of the 353 identified events were classified as SB-noLLJ. Our analysis focuses on the driest and wettest quarter of the SB-noLLJ events, with 14 events exhibiting very dry soils and 14 events exhibiting very wet soils. These 28 very dry/very wet events were further narrowed to 12 events based on the following criteria: 1 ) convective initiation occurred in Oklahoma, 2) convective initiation occurred between 1800 and 0000 UTC the following day, and 3) a convective event had an accumulation of $>0.10 \mathrm{in}$. $(2.5 \mathrm{~mm})$ of precipitation. Five of the 12 events are in the very dry category and 7 are in the very wet category. These criteria were used to eliminate events that occurred in the morning or late evening hours and to focus on events that occurred during the optimal time (i.e., midday and afternoon) for convection to occur (criteria 1 and 2). Events that did not produce significant precipitation accumulations were also not considered (criterion 3).

\section{d. NEXRAD event validation}

We utilized radar data from the National Centers for Environmental Prediction/Environmental Modeling Center 4-km gridded stage IV product to identify convective events that satisfy the three criteria listed in section $2 \mathrm{c}$ and to evaluate the robustness of the classification system. The stage IV radar products are mosaicked and provide hourly observations of precipitation accumulation across the contiguous United States (Lin and Mitchell 2005). The products undergo bias correction, quality control, and a series of automated algorithms and manual inspection.

We examined hourly stage IV radar-based precipitation accumulation and manually identified unorganized convective events that occurred from 0900 to 0200 UTC between May and September (2003-12). Precipitating systems previously identified by CMORPH were also reevaluated to ensure they were unorganized events. The manual identification procedure was completed according to a predetermined decision tree (Fig. 1), which approximates the classification system of Schoen and Ashley (2011). Storms were classified as quasi organized, cellular (unorganized or organized), and linear (organized). Their classification was developed based on previous studies examining the radar morphology of 


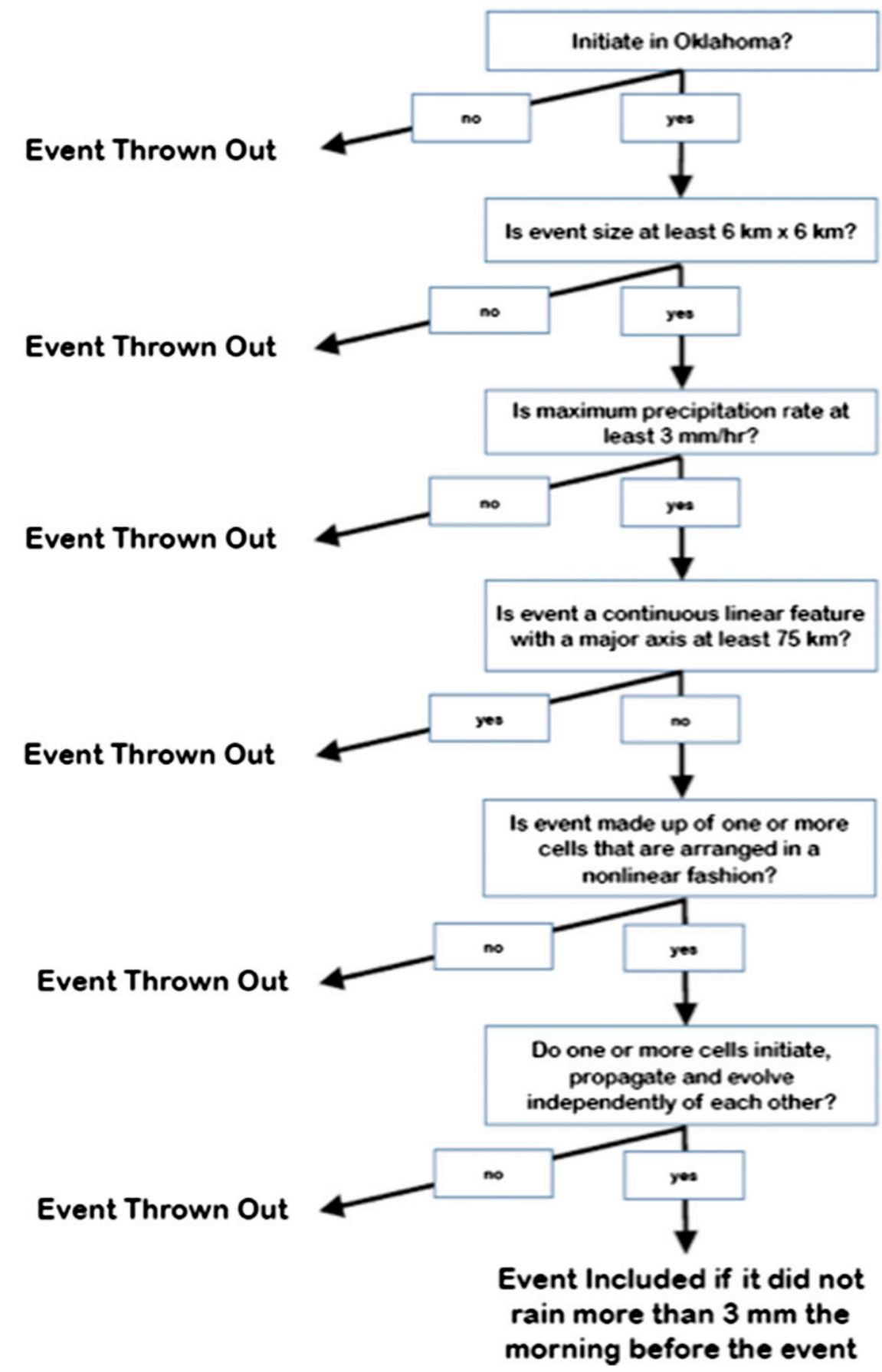

FIG. 1. A schematic of the decision tree that was used for manual identification of unorganized convective events.

convective storms (Parker and Johnson 2000; Klimowski et al. 2003). Our decision tree is based on six factors: 1) location of precipitation initiation, 2) minimum event size, 3) precipitation accumulation, 4) shape, 5) linearity and multicellularity, and 6) propagation of the event. The manual identification procedure is designed to exclude organized convective events associated with fronts, squall lines, or tropical storms. Manual inspection and classification from the radar dataset identified 419 events during the $10-\mathrm{yr}$ period, 66 more events than were identified by the automated CMORPH procedure that was employed by FRQ15. The larger number of events identified using radar is attributed to the higher temporal and spatial resolution of the NEXRAD product. The minimum 
event size identified using radar was $8 \mathrm{~km}$, still smaller than the $25-\mathrm{km}$ resolution of the CMORPH product. In addition, at hourly resolution NEXRAD is able to detect short-duration systems that the 3-h resolution CMORPH product cannot resolve.

\section{e. Backward-trajectory analysis}

Backward-trajectory analyses were run to evaluate the origin and direction of air parcels at different levels prior to the convective event and the general atmospheric patterns, and differences between wet and dry event trajectories are analyzed. The National Oceanic Atmospheric Administration (NOAA) Hybrid Single-Particle Lagrangian Integrated Trajectory model (HYSPLIT; http:// ready.arl.noaa.gov/HYSPLIT.php) was utilized to track the backward trajectory of an air parcel (represented in the model as a single particle) for each of the $12 \mathrm{SB}-$ noLLJ events identified by CMORPH. These backwardLagrangian trajectories were generated at 500 and $1000 \mathrm{~m}$ above ground level (AGL) $72 \mathrm{~h}$ prior to each event. All trajectories were initiated at 2100 UTC on the day of the event. The direction, distance traveled, and path of the air parcels from each event were assessed to interpret differences between very wet and very dry events. The model for events after 2004 used the Eta Data Assimilation System (EDAS) at 40-km grid spacing and events from 2003 and 2004 used the EDAS at $80-\mathrm{km}$ grid spacing. The starting point of the trajectories corresponds to the latitude and longitude pair for each event identified by CMORPH.

\section{f. NARR composites}

Composites of atmospheric and land surface variables' 3-hourly periods were generated from the NARR dataset. Sensible and latent heat fluxes from 0600 to 1800 UTC were averaged to represent daily (morning) surface heat fluxes prior to precipitation initiation. The morning averages were then converted to anomalies by subtracting the mean of a 30-day period surrounding the target day from 2003 to 2012. In this way, the sensible and latent heat flux anomalies represent the deviation from normal surface heat flux conditions during that time of the year. The $850-$ and $500-\mathrm{hPa}$ vector winds from 1500 UTC the morning of the events were averaged for each of the 12 SB-noLLJ events to represent the vector wind averaged across the continental United States. Composites of very dry soil events and very wet events are generated separately to compare and contrast spatial patterns. Additional variables for the case studies include accumulated total evaporation at the surface and downward radiation flux at the surface from 1200 and 1500 UTC, which represents the 3-h totals ending at 1200 and 1500 UTC. The values for each variable are estimated from the location identified by CMORPH. The 850- and 500-hPa wind composites for the case studies were also analyzed on the closest hour prior to the storm occurrence.

\section{Results}

\section{a. Reclassification of original CMORPH events}

The original 353 CMORPH events identified by FRQ15 were reclassified based on radar imagery to assess the robustness of the classification system. The comparison of the two lists (the original 353 CMORPH events and the 478 manually inspected radar events) allows us to validate the classification system, and to separate events that are part of a frontal boundary or a large mesoscale convective system from those that are unorganized (small scale) convection. Of the 88 SP-LLJ events identified by FRQ15, 38 (42\%) were determined to be unorganized (small scale) convection events. From the 157 SB-LLJ events identified, $56(36 \%)$ of these were identified as unorganized events. FRQ15 identified 50 SP-noLLJ events, and $24(48 \%)$ were identified as unorganized events. There were 56 SB-noLLJ events and 19 (34\%) unorganized events.

Frye and Mote (2010) found that the likelihood of convective initiation decreased in SB environments. Therefore, we expect that SB atmospheric conditions will result in a larger ratio of unorganized, small-scale events to organized storms associated with frontal boundaries. Based on the manual inspection of radar data, SB-LLJ and SB-noLLJ events had the lowest percentages that are identified as unorganized events. This is one indication that the classification utilized by Frye and Mote (2010) and FRQ15 may not accurately differentiate between unorganized and organized convection.

Separating events into small and large scales provides an additional method to assess whether convection preferentially occurs over wet or dry soils. That is, we expect that large-scale (organized) convection may have different results in terms of preferential occurrence over wet or dry soils than small-scale (unorganized) convection. When FRQ15 included all events identified with the CMORPH method, $55 \%$ of SP-LLJ events occurred over dry soils ( $<50$ th percentile) and $34 \%$ over very dry soils $(<25$ th percentile). However, when we include events identified by both CMORPH and the radarbased procedures used in this study, those numbers increase to $66 \%(55 \%)$ of events over dry (very dry) soils. The SP-noLLJ events identified by CMORPH occurred, in contrast, preferentially over wetter than normal soils, as $62 \%$ of events occurred over wet $(>50$ th percentile) and $20 \%$ over very wet ( $>75$ th percentile) 
soils. When we include events identified by CMORPH and radar-based methods, the percentages increased to $63 \%(33 \%)$ of events occurring over wet (very wet) soils. We therefore confirm that there is a statistically significant preference, at the $95 \%$ confidence level, for SP events to occur over dry soils when the LLJ was present and a preference for SP events to occur over wet soils when the LLJ was absent. This statistically significant preference, also reported in FRQ15, is even stronger when we only include events identified by both CMORPH and NEXRAD.

The results for SB events proved to be different than those for the SP events. There is no evidence that there is a stronger soil moisture signal in SB events when only considering small-scale precipitation events. The SBLLJ events identified by CMORPH occurred over dry soils $52 \%$ of the time and $23 \%$ of those events occurring over very dry soils. This slight preference for SB-LLJ events to occur over relatively dry soils is reversed when we include events identified in the radar dataset, such that only $39 \%$ of events occurred over dry soils. An even larger change in wet versus dry soil events was seen for the SB-noLLJ events. For those SB-noLLJ events identified by the CMORPH method, $61 \%$ occurred over wet soils. When only including events from the radar method, only $47 \%$ of events occurred over wet soils. FRQ15 found that there was a statistically significant preference for convection during SB-noLLJ events to occur over relatively wet soils, but this finding is not supported when only considering small-scale (unorganized) convective events that were identified using radar data in this study. Therefore, the preference for precipitation to occur over wet soils is enhanced by the presence of large-scale convective processes that did not initiate over the study region.

\section{b. Dry and wet composite analyses}

The locations with the maximum precipitation accumulation for each event were used to identify land and atmosphere conditions prior to and during the events. NARR composites were constructed using the five events associated with very dry soils and the seven events associated with very wet soils previously identified in section $2 \mathrm{c}$. The composites allow for the evaluation and comparison of the atmosphere and land surface conditions in the morning, prior to convective initiation. Mean atmospheric conditions (e.g., vector wind, and sensible and latent heat fluxes) were calculated for each event day.

Areas of existing convergence (associated with downward motion) and divergence (associated with upward motion) in the middle to upper troposphere can be determined using the $850-\mathrm{hPa}$ vector wind field. In the 1500 UTC composites, there were not areas of convergence or divergence in or near Oklahoma; however, these maps still share a relatively similar zonal pattern (Figs. 2a,b). The 850-hPa vector wind composite of the dry events reveals southwesterly winds into Oklahoma. The 850-hPa vector wind composite of the wet events indicates weaker winds flowing from the southwest. Both composites confirm the accuracy of the classification system that no LLJ was present when winds are less than $10 \mathrm{~m} \mathrm{~s}^{-1}$. These small discrepancies in wind velocity and direction decrease the possible influence of atmospheric conditions on convection occurring in Oklahoma. The differences in the $500-\mathrm{hPa}$ vector wind fields are more evident than in the 850 -hPa fields (Figs. 2c,d). Wind velocities for wet events did not change between 850 and $500 \mathrm{hPa}$, but the wind velocity for very dry events nearly doubled between the two atmospheric levels. The 500$\mathrm{hPa}$ vector winds were faster for the very dry events in comparison with the 500-hPa vector winds for the very wet events. Southwesterly winds from both very wet and very dry events ranged between 9 and $15 \mathrm{~m} \mathrm{~s}^{-1}$ and the spatial patterns were similar. Of the very dry events, there was a region of fast-moving air at $500 \mathrm{hPa}$ flowing from the southwest characterized as a weak jet streak. This pattern was greatly influenced by two individual events on 1 and 3 May 2003. The 500-hPa vector fields from these two days show southeasterly winds exceeding $50 \mathrm{~m} \mathrm{~s}^{-1}$ in southern California stretching into the Texas Panhandle and far western Oklahoma. These differences in vector winds are noteworthy considering that the strength of the soil moisture signal is associated with isolated convective storms.

Because soil moisture feedbacks to the atmosphere manifest through surface heat flux anomalies, we expect significant differences in spatial patterns of latent and sensible heat flux between the dry and wet composites. We examine composites of sensible and latent heat flux anomalies the morning prior to each of the very dry and very wet events. Composites for the five dry events show diminished latent heat flux (Fig. 3a) in the central section of the state, with stronger than normal latent heating on the eastern edge and panhandle regions of the state. Not surprisingly, sensible heat (Fig. 3b) composited for the dry events reveals the opposite pattern, with much higher than normal values in the central, northern, and southeastern parts of the state, contrasted with small areas of diminished sensible heating across the northeast corner and panhandle region. All five of the very dry events occurred within the region of anomalously strong sensible heating. Relatively strong (limited) sensible (latent) heating is consistent with moisture limitations from drier than normal soils.

Latent heat flux composited from the very wet events (Fig. 3c) reveals a contrasting pattern of latent heating 

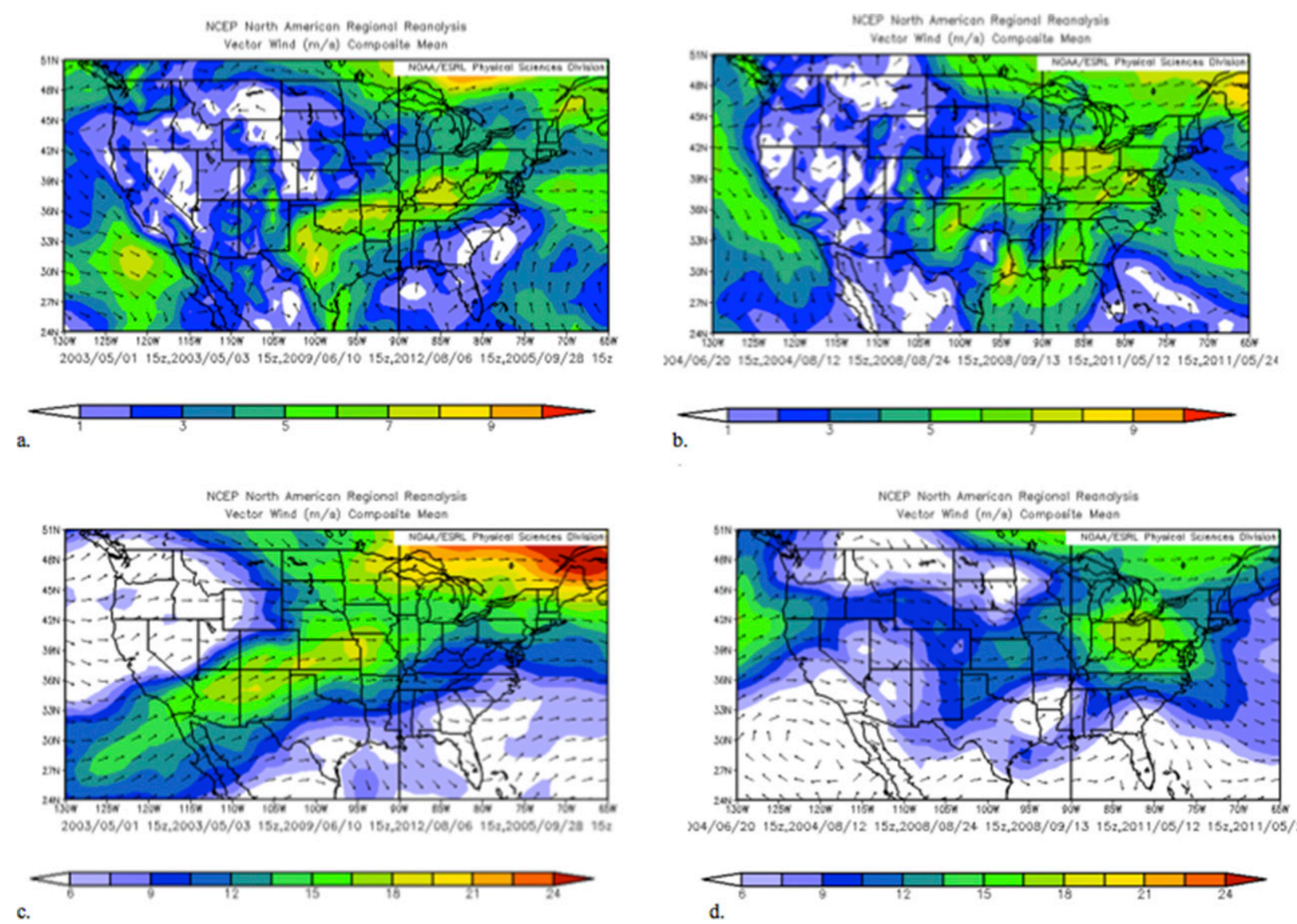

FIG. 2. Vector wind composites at (a),(b) 850 and (c),(d) $500 \mathrm{hPa}$ at 1500 UTC for (left) dry and (right) wet events. Note that the wind speed color scales are different for 850 and $500 \mathrm{hPa}$ to compare the vector winds between dry and wet events. [NCEP-NCAR reanalysis data were provided by the NOAA/OAR/ESRL PSD (http://www.esrl.noaa.gov/psd/).]

compared with the very dry events (Fig. 3a), with higher flux values in the central portion of the state and normal to below normal values along the eastern edge and over the panhandle regions. Later, a pattern that is roughly opposite of the sensible heat flux anomalies from the very wet events, with lower sensible heat flux values in the central-southern portion of Oklahoma, and close to normal values everywhere else is presented (Fig. 5d).

HYSPLIT was used to generate airmass backward trajectories for each very dry and very wet event, starting at 500 and $1000 \mathrm{~m}$ AGL. The majority of the very dry event trajectories approached from the southwest, with the exception of 6 August 2012 and 3 May 2003 (Fig. 4a). These trajectories also exhibit anticyclonic curvature, a trend that is consistent with the $850-\mathrm{hPa}$ vector wind patterns and the presence of a high pressure system over the region. The trajectory pattern for the very wet events reveals air masses moving from the southeast out of the Gulf of Mexico (Fig. 4b). The trajectories also appear to cover a greater distance during the very wet events. This indicates that air parcels moved more quickly at both levels during wet events. Based on these backward trajectories, we hypothesize that wet events received more moisture from the Gulf of Mexico than do dry events. The influx of moisture may have helped induce precipitation in Oklahoma and could confound or mask any impact from the land surface.

\section{c. Case study 1: 6 August 2012}

The event on 6 August 2012 occurred over very dry soils (seventh percentile). This event was chosen to represent a localized mesoscale event as opposed to an event that is part of a larger system. On 6 August 2012, isolated thunderstorms developed over the Great Plains in the late afternoon. A weak frontal system located in southern Colorado and a stationary front stretching through southern Oklahoma created a moist and moderately unstable air mass, favorable for weakly organized thunderstorms (Fig. 5). Daytime heating also supported the development of thunderstorms in the afternoon. An isolated thunderstorm from the northwest moved through southwest Oklahoma City, Oklahoma, 

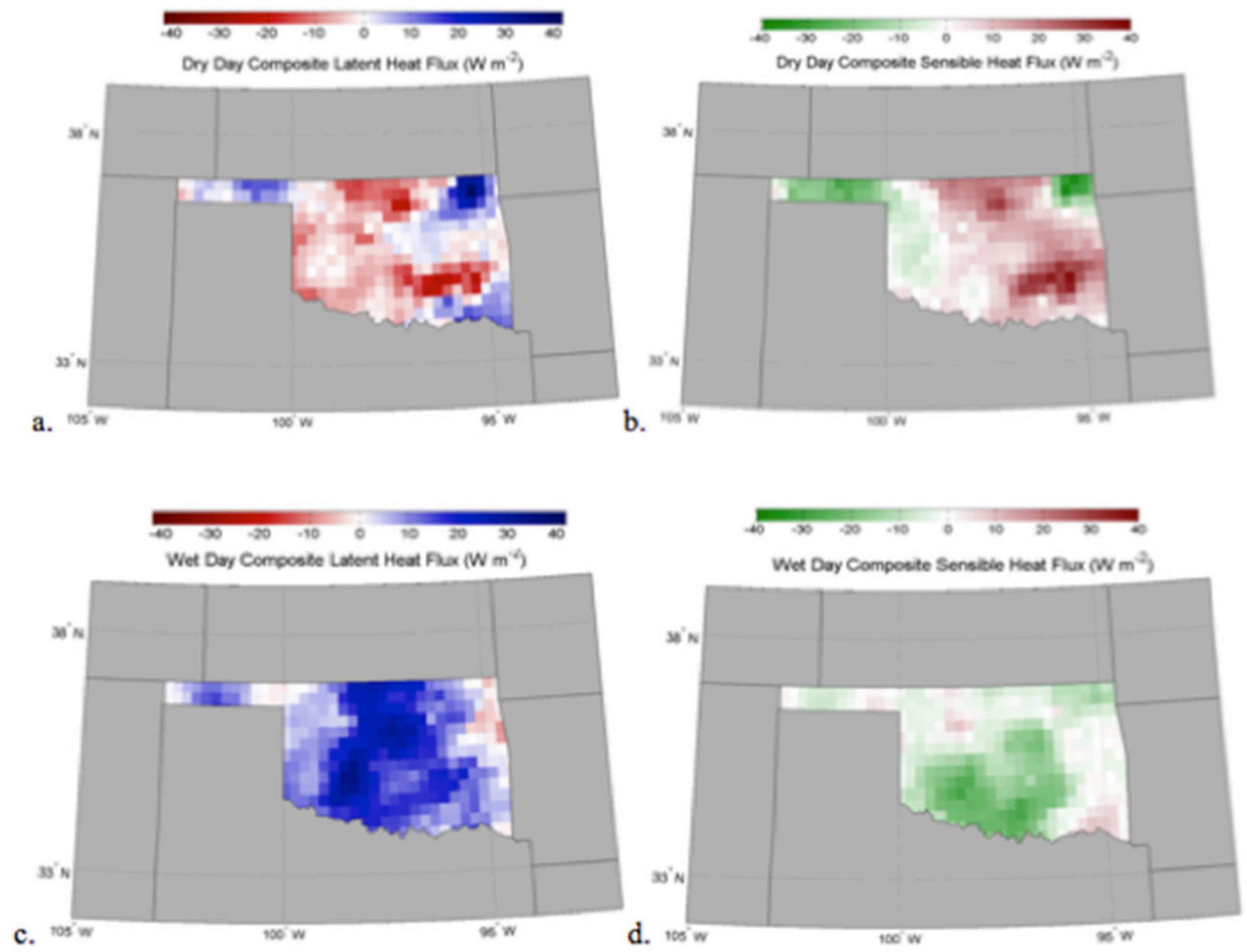

FIG. 3. Composites of (a),(c) latent heat flux and (b),(d) sensible heat flux anomalies for (top) dry and (bottom) wet events.

and was one of the CMORPH events (i.e., received the highest precipitation accumulation at this location).

During the $3 \mathrm{~h}$ prior to the event, 850 -hPa vector winds were variable in Oklahoma (Fig. 6a). Northwesterly winds were present in eastern Oklahoma, while there was a southwesterly wind in northwestern Oklahoma. From the 500-hPa wind field, there were weak northwesterly winds throughout the Great Plains, and the high pressure situated over Colorado and New Mexico influenced winds at upper levels (Fig. 6b).

The classification criteria are intended to isolate and eliminate events that are caused by large-scale atmospheric processes. By doing so, we are able to more clearly isolate the influence that soil moisture has (if any) on precipitation. Latent and sensible heat fluxes have a role in creating instability in the atmosphere. The sensible heating the morning before precipitation initiated was about $20 \mathrm{~W} \mathrm{~m}^{-2}$ higher than normal during that time, while latent heating was nearly $10 \mathrm{~W} \mathrm{~m}^{-2}$ lower than normal, leading to a dramatic increase in Bowen ratio. This substantial energy exchange at the surface implies that the majority of the available energy was used to heat the air and the ground (sensible heat) (Oladosu et al. 2007). The ingredients for convective activity in this case are shown to have had a greater effect on the development of these isolated thunderstorms. Surface heating enhanced instability in the low-level atmosphere. The lifted index over the course of the morning and early afternoon showed a decrease over time indicating increased instability and an enhanced probability of convective activity.

\section{d. Case study 2: 24 May 2011}

On the morning of 24 May 2011, the Storm Prediction Center (SPC) forecast an outbreak of supercell thunderstorms. They indicated that severe thunderstorms were possible throughout the lower Great Plains. A classic spring setup is characterized by a dominant surface low with an attendant dryline. The accompanying warm front to the north corresponds with warm air and 

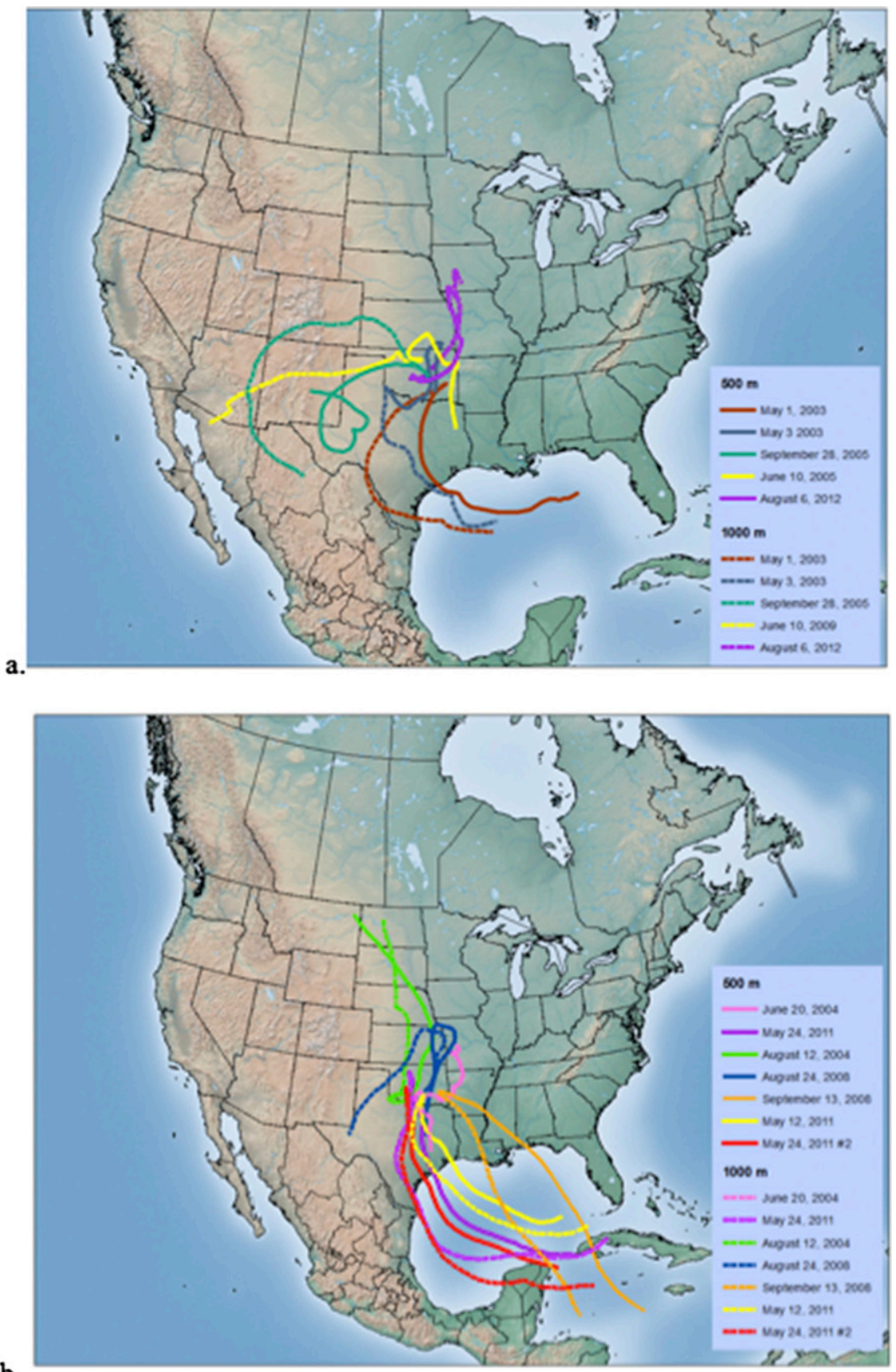

b.

FIG. 4. Backward trajectories from the locations of highest precipitation accumulation for each (a) dry and (b) wet event at 500 (solid lines) and 1000 (dashed lines) m AGL.

moisture advection from the Gulf of Mexico (Fig. 7). The atmosphere became increasingly unstable as temperatures warmed in the early afternoon and dewpoint temperatures increased to $20^{\circ} \mathrm{C}$. The atmospheric cap eventually eroded and rapid cell development occurred along the dryline as it propagated eastward. A strong line of thunderstorms developed in the afternoon (SPC Mesoscale Reports 0925, 0934, and 0938), and a number of convective thunderstorm events, as identified by CMORPH, occurred to the southeast of Oklahoma City. The soil conditions at the CMORPH location were very wet with soil moisture in the 85th percentile.

Strong $850-\mathrm{hPa}$ vector winds from the south signify the presence of an LLJ (Fig. 8a), despite the classification procedure categorizing the event as not being associated with the LLJ. The 850 -hPa vector winds varied 


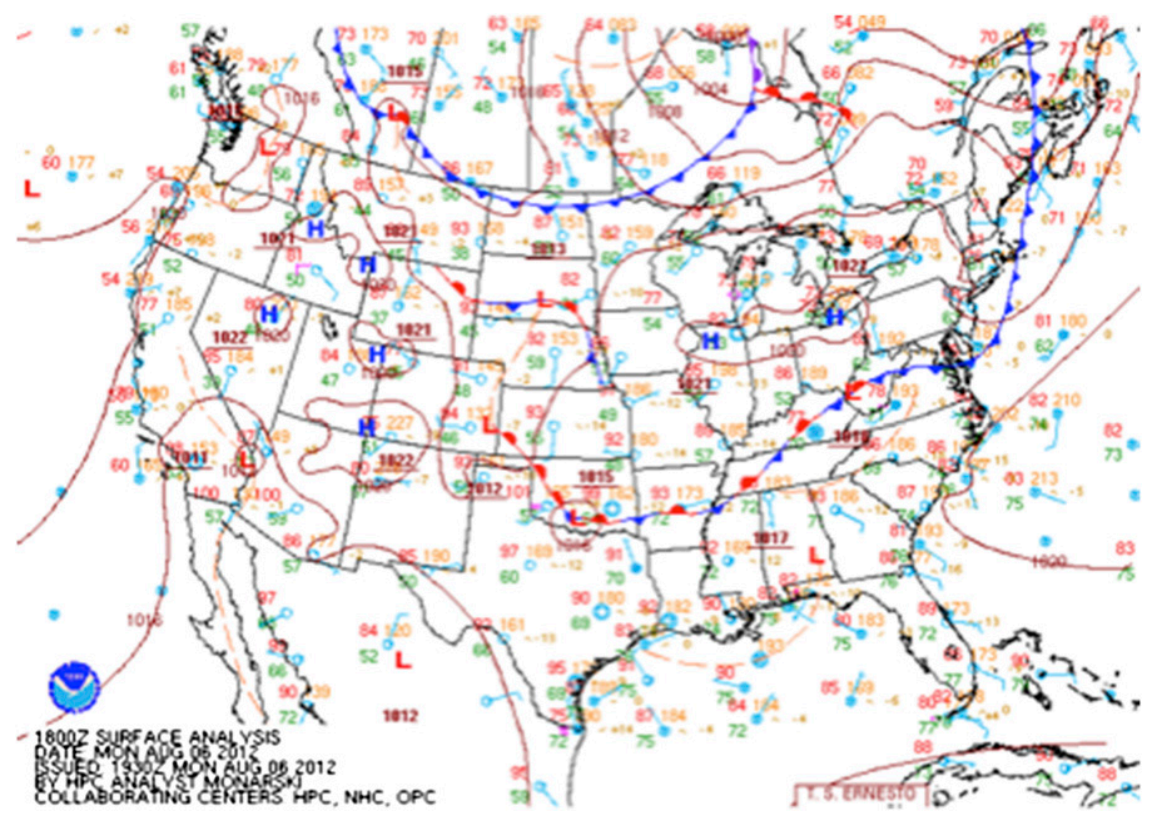

FIG. 5. National Weather Service (NWS) surface analysis at 1800 UTC 6 Aug 2012.

between 14 and $18 \mathrm{~m} \mathrm{~s}^{-1}$, well above the low-level jet criteria (Fig. 8a). The 500-hPa winds exhibited a very strong zonal flow (Fig. 8b). The strongest winds were over west Texas and southern New Mexico. The midlevel trough over Oklahoma, an area of divergence and rising air aloft, was enhanced as a result of winds veering with height and southwestern Oklahoma was located in the right-entrance region of a $250-\mathrm{hPa}$ jet streak. It should be noted that the presence of an LLJ was determined the morning of the event and not when the event took place, which indicates a possible drawback of the classification system. For example, the strength of the LLJ is strongly tied to pressure gradients related to surface heating anomalies over the southern Great Plains (Bosilovich and Sun 1999). Strong surface heating during the morning and afternoon may, therefore, cause the LLJ to strengthen during the course of the day, and could lead to a false classification of an absent LLJ.

Sensible heat flux the morning before this event was less than normal by nearly $90 \mathrm{~W} \mathrm{~m}^{-2}$, while latent heating was higher than normal by about the same amount. The higher latent heat flux relative to the dry-event case suggests that most of the available energy is converted into evaporating water within the soil surface. The Bowen ratio of 1.27 reveals a weak soil moisture signal; that is, synoptic conditions were likely responsible for convective activity.

\section{Discussion}

Atmospheric conditions from the morning prior to convection may provide insight into the atmospheric conditions leading up to the initiation of rainfall (Table 1). There is a distinct difference in Bowen ratio and accumulated total evaporation, but relatively similar values of downward radiative flux. As Figs. 3a-d show, the largest difference between the dry and wet events is in how the radiative fluxes are partitioned. Composites of surface heat flux from very dry events show strong partitioning of sensible heat over latent heat flux, consistent with drier than normal soils. In contrast, composites of surface heat flux from very wet soils show oppositely strong partitioning of latent over sensible heating, again consistent with relatively wet soils and abundant moisture for evaporation. These findings suggest that soil moisture does play a role in the energy exchange in the atmosphere.

The case studies focus on events that are classified as isolated, unorganized convection forming under SB conditions with no LLJ present. The 6 August 2012 event was characterized by isolated thunderstorms and occurred over dry soils. The 24 May 2011 event occurred over relatively wet soils and was part of a large line of broken thunderstorms moving from west to east. Sufficient moisture, lift, and instability formed associated with the dryline, creating the strong potential for severe convection. The influence of large-scale atmospheric disturbances on the location of convective precipitation in this case is considered much stronger than the influence of the land surface. Despite these atmospheric conditions, this event was originally classified as SB-noLLJ. Through further analysis, we determined that all seven very wet events were not small-scale (unorganized) convective 


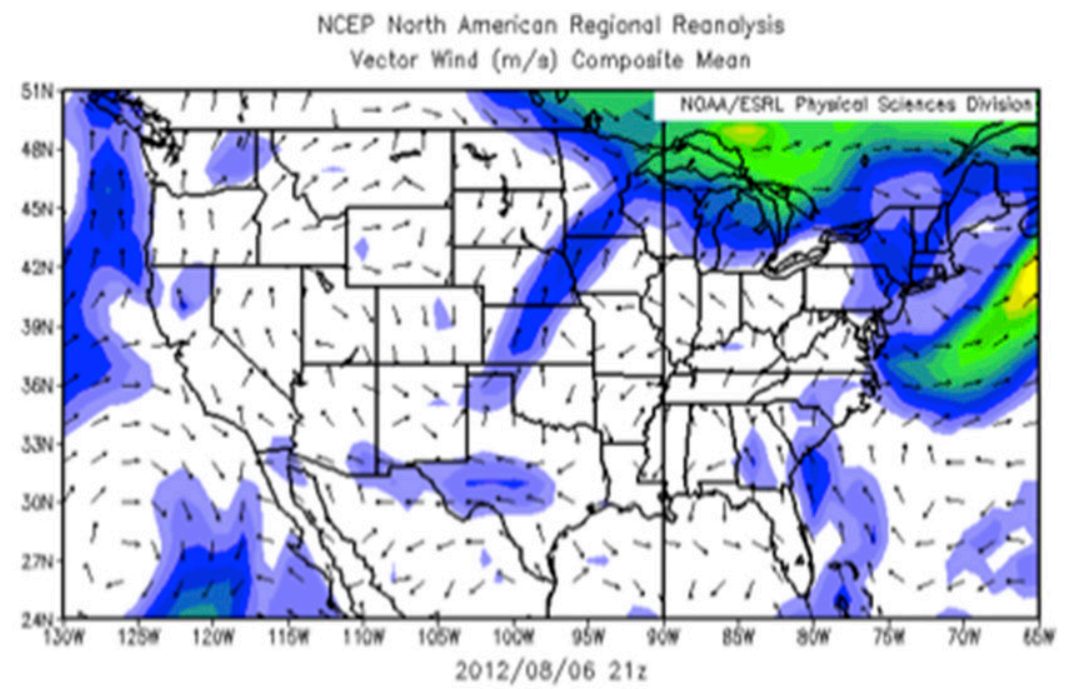

a.
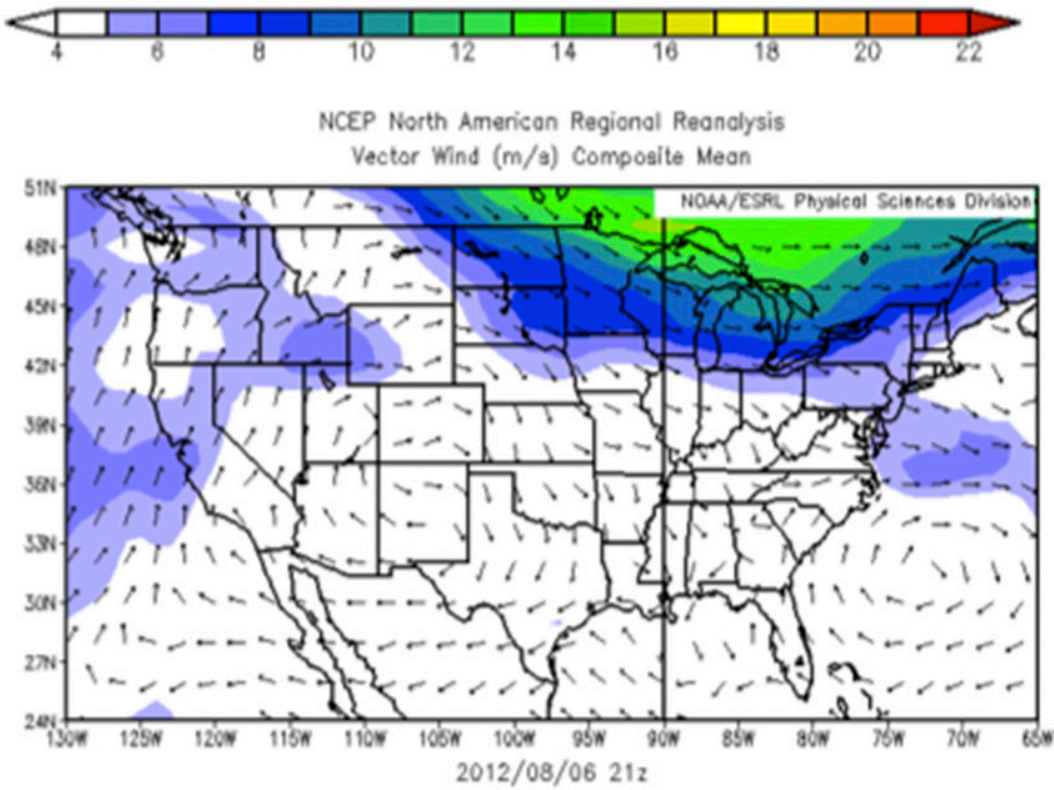

b.

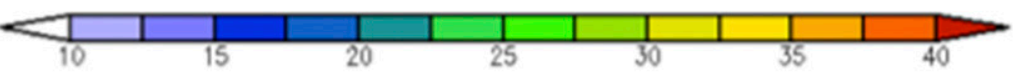

FIG. 6. Vector wind composites from (a) 850 and (b) $500 \mathrm{hPa}$ taken at 2100 UTC 6 Aug 2012. Note that the wind speed color scales are different for 850 and $500 \mathrm{hPa}$. NCEP-NCAR reanalysis data were provided as in Fig. 2.

events. Instead, they were associated with stratiform precipitation or developed ahead of a cold front.

Previous studies examining potential soil moisture feedbacks identify mechanisms for dry soils to initiate convection (Santanello et al. 2011), as well as initiation over wet soils (Brimelow et al. 2011). FRQ15 found a strong preference for precipitation to occur over wet soils, when atmospheric conditions were otherwise not conducive to convection. Further evaluation of the findings of FRQ15 in this study suggests that the classification properly discerned unorganized from organized convection for those events initiating over drier than normal soils. In contrast, the classification method was unable to distinguish unorganized from organized convective events over wet soils. Consequently, the majority of wet soil events originally classified as SB with weak 


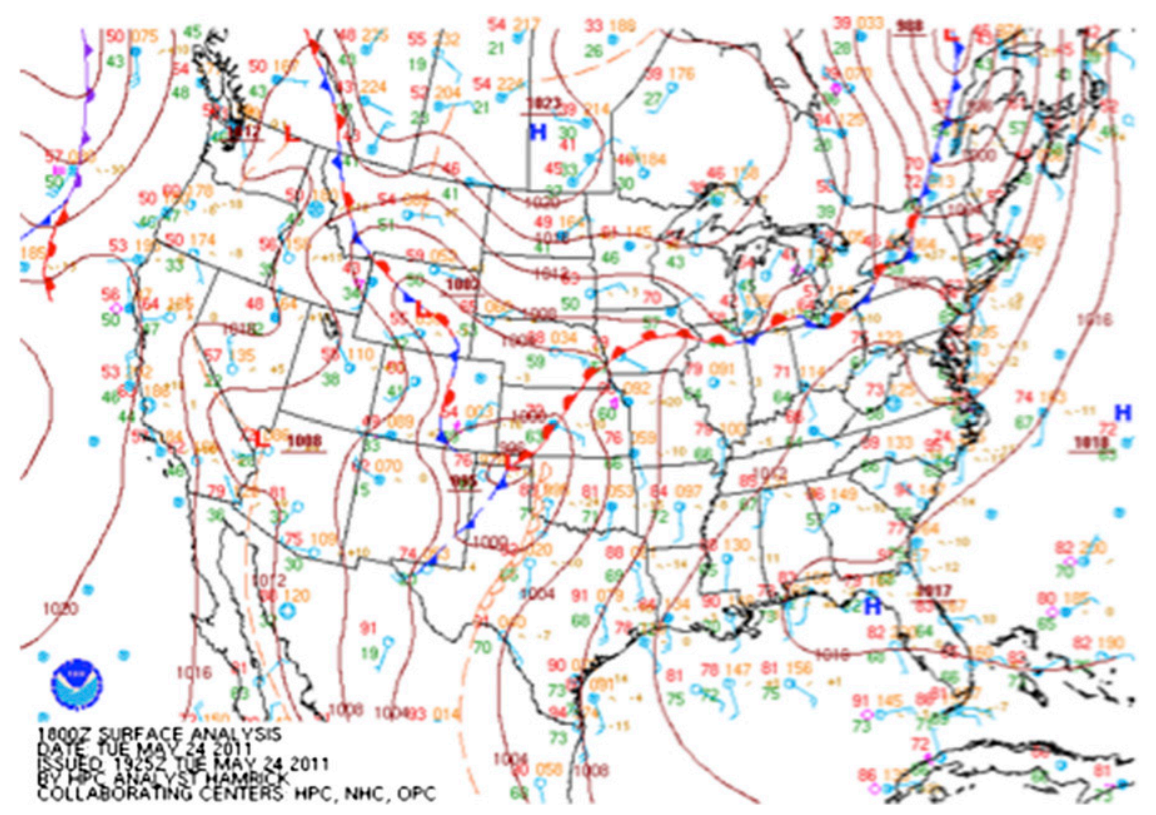

FIG. 7. NWS surface analysis at 1800 UTC 24 May 2011.

synoptic flow (e.g., Carleton et al. 2008) were actually associated with large-scale atmospheric systems. Our results highlight potential concerns regarding the classification system used by FRQ15, because that method does not take into account the overall synoptic conditions of the atmosphere. Moisture transport from remote regions and instability forced by mechanical lifting, both associated with larger-scale atmospheric disturbances, may confound any signal of land surface feedback to the atmosphere. Therefore, sound conclusions that convection and precipitation initiate or occur preferentially over dry/wet soils or strong gradients in surface heat flux cannot be reached without sufficient knowledge of the mechanisms through which the convection initiated. Supplementing the classification system used by FRQ15 with manual inspection of radar precipitation does not completely resolve this issue, but it does help to identify the synoptic context of the convective events that were identified (i.e., whether they are organized or unorganized convection).

One caveat of the approach used in this study is that it relies on expert (manual) evaluation of radar data to identify unorganized convective events. This raises questions about the reproducibility of the identification of events. To evaluate the overall robustness of the identification procedure, all SB-noLLJ events were classified independently by two researchers. Overall, there was $96 \%$ agreement (27 of 28) in classifying SB-noLLJ events as unorganized or organized convection.

Based on the sample of 12 SB-noLLJ events, our results suggest that events that occurred over drier than normal soils are indeed local-scale unorganized convection. The majority of these events over wetter than normal soils; however, are related to or are direct manifestations of synoptic-scale atmospheric disturbances. The initial synoptic-dynamic classification system was based on the stability of the morning-time, synoptic-scale atmosphere as well as the presence or absence of the lowlevel jet. The results presented here suggest that although these aspects can be used to generally characterize atmospheric conditions, they are not sufficient to appropriately associate convection with small- or larger-scale processes. To maintain a fully automated classification system that could delineate local and remote forcing mechanisms, additional metrics such as the convective triggering potential as defined by Findell and Eltahir (2003) and the morning buoyant mixing temperature (Tawfik and Dirmeyer 2014) should be considered. These metrics will create a more thorough classification system by incorporating supplementary atmospheric conditions conducive for deep convection. In addition, changes in surface air temperature and humidity may help determine if soil moisture anomalies do modify atmospheric conditions leading to convection.

We acknowledge that the results of this study are based on a small sample size of convective events. However, similar studies focusing on meteorological phenomena have successfully employed small sample sizes. For example, Ashley et al. (2007) drew conclusions from 29 derecho events over the United States. Van Den Broeke et al. (2008) examined tornado life cycles in the southern Great Plains using seven tornado events. Burke and Schultz (2004) as well as Adams-Selin and Johnson (2010), 


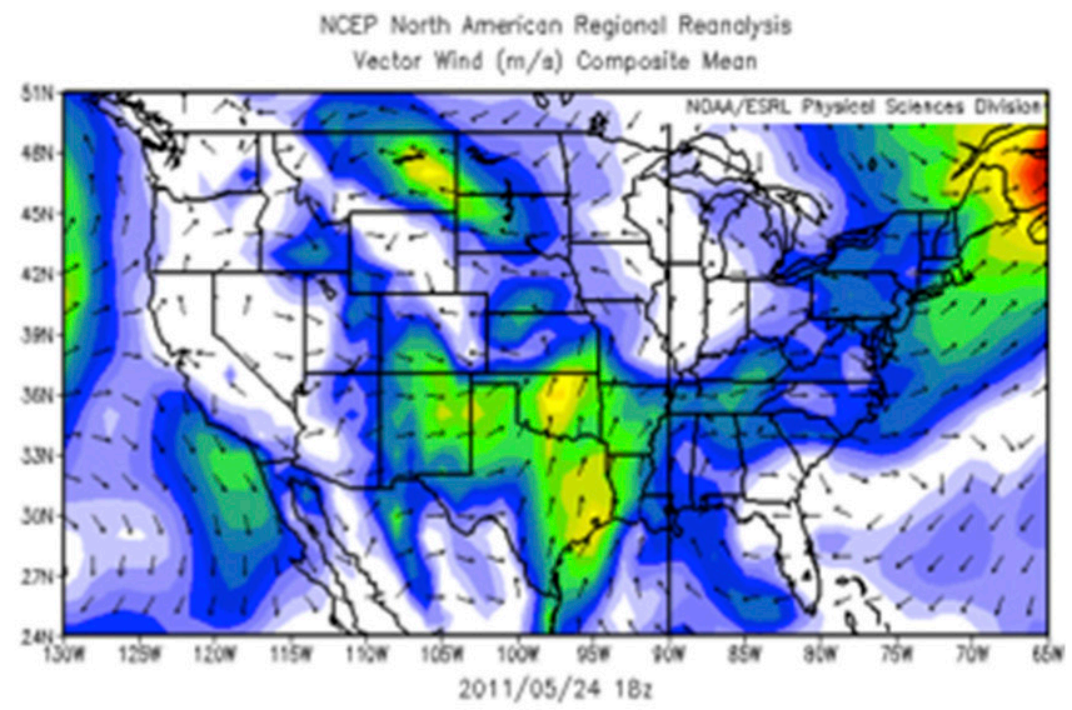

a.
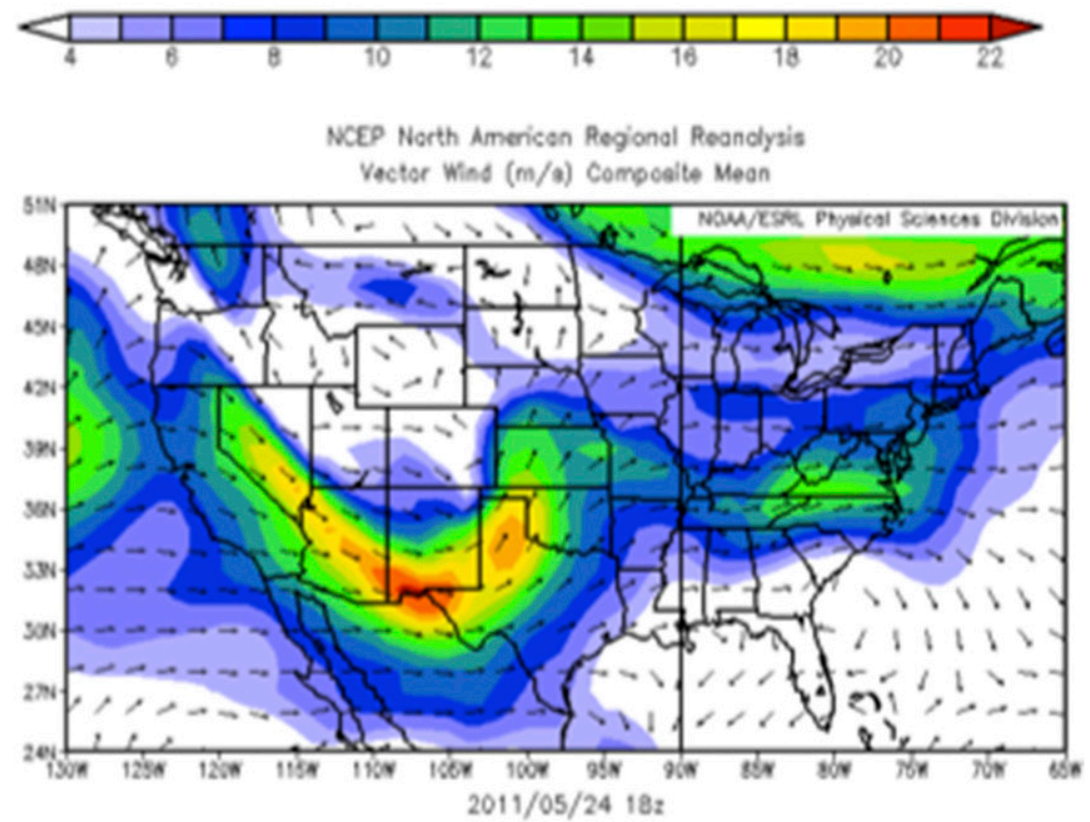

b.

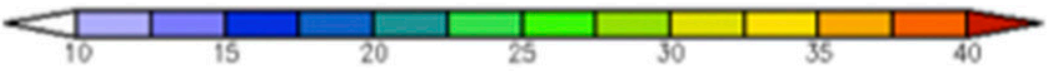

FIG. 8. As in Fig. 6, but for 1800 UTC 24 May 2011.

characterized atmospheric conditions associated with bow echoes from 51 and 36 events, respectively. Based on the 12 events that we evaluated, we argue that the classification system used by FRQ15 does not accurately differentiate between organized and unorganized convective events during SB conditions and when the LLJ is not present. Investigation of all $56 \mathrm{SB}-$ noLLJ events identified by FRQ15 is beyond the scope of this study. However, even if the seven wet events that we examined were the only ones misclassified, an error rate of $13 \%(7 / 56)$ is still cause for concern. Further research is needed to develop a more robust classification scheme.

\section{Conclusions}

This study evaluated the robustness of the classification system employed by FRQ15. We focused on 12 events that occurred in SB environments where the 
TABLE 1. Summary of several variables for 6 Aug 2012 (dry case) and 24 May 2011 (wet case) taken from 3-h NARR composites at 1200 and 1500 UTC.

\begin{tabular}{lccccc}
\hline \hline & $\begin{array}{c}\text { Sensible } \\
\text { heat }\left(\mathrm{W} \mathrm{m}^{-2}\right)\end{array}$ & $\begin{array}{c}\text { Latent } \\
\text { heat }\left(\mathrm{W} \mathrm{m}^{-2}\right)\end{array}$ & $\begin{array}{c}\text { Bowen } \\
\text { ratio }\end{array}$ & $\begin{array}{c}\text { Accumulated total } \\
\text { evaporation }\left(\mathrm{kg} \mathrm{m}^{-2}\right)\end{array}$ & $\begin{array}{c}\text { Downward radiative } \\
\text { flux }\left(\mathrm{W} \mathrm{m}^{-2}\right)\end{array}$ \\
\hline 6 Aug 2012 & -430 & -45 & 9.56 & 0.15 & 1065 \\
24 May 2011 & -440 & -280 & 1.57 & 1.45 & 1300 \\
\hline
\end{tabular}

Great Plains LLJ was not present to determine whether these were accurately classified as unorganized convection. Although there is a small sample size, our results show that the classification system employed by FRQ15 fails to differentiate between organized and unorganized convection under SB-noLLJ conditions. We conclude that past studies that have used this classification to study how soil moisture influences unorganized convection should be revisited. The majority of events that occurred over wet soils were not isolated and localized storms but, instead, were associated with mesoscale convective systems. Therefore, these events were likely not strongly influenced by soil moisture. Specifically, two case studies of events classified as SB-noLLJ were evaluated, one that occurred over very dry soils (6 August 2012) and one that occurred over very wet soils (24 May 2011). Moisture sources and energy conditions were examined to assess the potential atmospheric modification by the land surface. The 24 May 2011 event was part of a broken line of supercells influenced by a large-scale low pressure system and accompanying dryline. This event is one example that the classification system failed to identify as SP-LLJ but instead identified as SB-noLLJ.

We conclude that incorporating additional metrics to evaluate atmosphere conditions within the classification system will likely yield more conclusive results. Our results demonstrate that it is important to account for the potential confounding influence of synoptic-scale atmospheric conditions in order to accurately identify the potential relationships between soil moisture and convective precipitation.

Acknowledgments. This work was supported by the National Science Foundation (Award AGS-1056796). The use of the reanalysis product, the NCEP-NCAR reanalysis dataset, provided by the NOAA/OAR/ESRL/ PSD (http://www.esrl.noaa.gov/psd/), is gratefully acknowledged. The authors thank the anonymous reviewers for their helpful comments on the manuscript.

\section{REFERENCES}

Adams-Selin, R. D., and R. H. Johnson, 2010: Mesoscale surface pressure and temperature features associated with bow echoes. Mon. Wea. Rev., 138, 212-227, doi:10.1175/ 2009MWR2892.1.

Alfieri, L., P. Claps, P. D’Odorico, F. Laio, and T. M. Over, 2008: An analysis of the soil moisture feedback on convective and stratiform precipitation. J. Hydrometeor., 9, 280-291, doi:10.1175/ 2007JHM863.1.

Allard, J., and A. M. Carleton, 2010: Mesoscale associations between Midwest land surface properties and convective cloud development in the warm season. Phys. Geogr., 31, 107-136, doi:10.2747/0272-3646.31.2.107.

Ashley, W. S., T. L. Mote, and M. L. Bentley, 2007: The extensive episode of derecho-producing convective systems in the United States during May and June 1998: A multi-scale analysis and review. Meteor. Appl., 14, 227-244, doi:10.1002/ met.23.

Bonner, W. D., 1968: Climatology of the low level jet. Mon. Wea. Rev., 96, 833-850, doi:10.1175/1520-0493(1968)096<0833: COTLLJ $>2.0 . \mathrm{CO} ; 2$.

Bosilovich, M. G., and W.-Y. Sun, 1999: Numerical simulation of the 1993 Midwestern flood: Land-atmosphere interactions. $J$. Climate, 12, 1490-1505, doi:10.1175/1520-0442(1999)012<1490: $\mathrm{NSOTMF}>2.0 . \mathrm{CO} ; 2$.

Brimelow, J. C., J. M. Hanesiak, and W. R. Burrows, 2011: Impacts of land-atmosphere feedbacks on deep, moist convection on the Canadian Prairies. Earth Interact., 15, doi:10.1175/ 2011EI407.1.

Burke, P. C., and D. M. Schultz, 2004: A 4-yr climatology of coldseason bow echoes over the continental United States. Wea. Forecasting, 19, 1061-1074, doi:10.1175/811.1.

Carleton, A. M., D. L. Arnold, D. J. Travis, S. Curran, and J. O. Adegoke, 2008: Synoptic circulation and land surface influences on convection in the Midwest U.S. "Corn Belt" during the summers of 1999 and 2000. Part I: Composite synoptic environments. J. Climate, 21, 3389-3414, doi:10.1175/ 2007JCLI1578.1.

Delworth, T. L., and S. Manabe, 1988: The influence of potential evaporation on the variabilities of simulated soil wetness and climate. J. Climate, 1, 523-547, doi:10.1175/ 1520-0442(1988)001<0523:TIOPEO > 2.0.CO;2.

Dirmeyer, P. A., F. J. Zeng, A. Ducharne, J. C. Morrill, and R. D. Koster, 2000: The sensitivity of surface fluxes to soil water content in three land surface schemes. J. Hydrometeor., 1, 121-134, doi:10.1175/1525-7541(2000)001<0121: TSOSFT $>2.0 . \mathrm{CO} ; 2$.

Ek, M. B., and A. A. M. Holtslag, 2004: Influence of soil moisture on boundary layer cloud development. J. Hydrometeor., 5, 86-99, doi:10.1175/1525-7541(2004)005<0086:IOSMOB>2.0.CO;2.

Entin, J. K., A. Robock, K. Y. Vinnikov, S. E. Hollinger, S. Liu, and A. Namkhai, 2000: Temporal and spatial scales of observed soil moisture variations in the extratropics. J. Geophys. Res., 105, 11 865-11 877, doi:10.1029/2000JD900051.

Findell, K. L., and E. A. B. Eltahir, 2003: Atmospheric controls on soil moisture-boundary layer interactions. Part I: 
Framework development. J. Hydrometeor., 4, 552-569, doi:10.1175/1525-7541(2003)004<0552:ACOSML>2.0.CO;2.

Ford, T. W., A. D. Rapp, and S. M. Quiring, 2015: Does afternoon precipitation occur preferentially over dry / or wet soils in Oklahoma? J. Hydrometeor., 16, 874-888, doi:10.1175/ JHM-D-14-0005.1.

Frye, J. D., and T. L. Mote, 2010: The synergistic relationship between soil moisture and the low-level jet and its role on the prestorm environment in the southern Great Plains. J. Appl. Meteor. Climatol., 49, 775-791, doi:10.1175/2009JAMC2146.1.

Gu, L., and Coauthors, 2006: Direct and indirect effects of atmospheric conditions and soil moisture on surface energy partitioning revealed by a prolonged drought at a temperate forest site. J. Geophys. Res., 111, D16102, doi:10.1029/ 2006JD007161.

Higgins, R. W., Y. Yao, E. S. Yarosh, P. E. Janowiak, and K. C. Mo, 1997: Influence of the Great Plains low-level jet on summertime precipitation and moisture transport over the central United States. J. Climate, 10, 481-507, doi:10.1175/ 1520-0442(1997)010<0481:IOTGPL > 2.0.CO;2.

Illston, B. G., J. B. Basara, C. A. Fiebrich, K. C. Crawford, and E. Hunt, 2008: Mesoscale monitoring of soil moisture across a statewide network. J. Atmos. Oceanic Technol., 25, 167-182, doi:10.1175/2007JTECHA993.1.

Jones, A. R., and N. A. Brunsell, 2009: Energy balance partitioning and net radiation controls on soil moisture-precipitation feedbacks. Earth Interact., 13, doi:10.1175/2009EI270.1.

Joyce, R. J., J. E. Janowiak, P. A. Arkin, and P. Xie, 2004: CMORPH: A method that produces global precipitation estimates from passive microwave and infrared data at high spatial and temporal resolution. J. Hydrometeor., 5, 487-503, doi:10.1175/ 1525-7541(2004)005<0487:CAMTPG >2.0.CO;2.

Karl, T. R., 1986: Sensitivity of the Palmer drought severity index and Palmer's Z-index to their calibration coefficients including potential evapotranspiration. J. Climate Appl. Meteor., 25, 77-86, doi:10.1175/1520-0450(1986)025<0077:TSOTPD>2.0.CO;2.

Klimowski, B. A., M. J. Bunkers, M. R. Hjelmfelt, and J. N. Convert, 2003: Severe convective windstorms over the northern high plains of the United States. Wea. Forecasting, 18, 502-519, doi:10.1175/1520-0434(2003)18<502:SCWOTN > 2.0.CO;2.

Koster, R. D., and M. J. Suarez, 2004: Suggestions in the observational record of land-atmosphere feedback operating at seasonal time scales. J. Hydrometeor., 5, 567-572, doi:10.1175/ 1525-7541(2004)005<0567:SITORO >2.0.CO;2.

Legates, D. R., R. Mahmood, D. F. Levia, T. L. DeLiberty, S. M. Quiring, C. Houser, and F. Nelson, 2011: Soil moisture: A central and unifying theme in physical geography. Prog. Phys. Geogr., 35, 65-86, doi:10.1177/0309133310386514.

Lin, Y., and K. E. Mitchell, 2005: The NCEP Stage II/IV hourly precipitation analyses: Development and applications. Preprints, 19th Conf. on Hydrology, San Diego, CA, Amer. Meteor. Soc., 1.2. [Available online at https://ams.confex. com/ams/pdfpapers/83847.pdf.]

Mei, R., and G. Wang, 2011: Impact of sea surface temperature and soil moisture on summer precipitation in the United States based on observational data. J. Hydrometeor., 12, 1086-1099, doi:10.1175/2011JHM1312.1.

Mesinger, G., and Coauthors, 2006: North American Regional Reanalysis. Bull. Amer. Meteor. Soc., 87, 343-360, doi:10.1175/ BAMS-87-3-343.

Mostovoy, G. V., and V. G. Anantharaj, 2008: Observed and simulated soil moisture variability over the lower Mississippi delta region. J. Hydrometeor., 9, 1125-1150, doi:10.1175/ 2008JHM999.1.

Oladosu, O. R., O. O. Jegede, L. A. Sunmonu, and A. T. Adediji, 2007: Bowen ratio estimation of surface energy fluxes in a humid tropical agricultural site, Ile-Ife, Nigeria. Indian J. Radio Space Phys., 36, 213-218.

Parker, M. D., and R. H. Johnson, 2000: Organizational modes of midlatitude mesoscale convective systems. Mon. Wea. Rev., 128, 3413-3436, doi:10.1175/1520-0493(2001)129<3413: OMOMMC $>2.0 . \mathrm{CO} ; 2$

Pielke, R. A., 2001: Influence of the spatial distribution of vegetation and soils on the prediction of cumulus convective rainfall. Rev. Geophys., 39, 151-177, doi:10.1029/ 1999RG000072.

Rabin, R. M., D. J. Stensrud, S. Stader, P. J. Wetzel, and M. Gregory, 1990: Observed effects of landscape variability on convective clouds. Bull. Amer. Meteor. Soc., 71, 272-280, doi:10.1175/1520-0477(1990)071<0272: OEOLVO $>2.0 . \mathrm{CO} ; 2$

Robock, A., K. Y. Vinnikov, G. Srinivasan, J. K. Entin, S. E. Hollinger, N. A. Speranskaya, S. Liu, and A. Namkhai, 2000: The Global Soil Moisture Data Bank. Bull. Amer. Meteor. Soc., 81, 1281-1299, doi:10.1175/1520-0477(2000)081<1281: TGSMDB $>2.3 . \mathrm{CO} ; 2$.

Santanello, J. A., C. D. Peters-Lidard, and S. V. Kumar, 2011: Diagnosing the sensitivity of local land-atmosphere coupling via the soil moisture-boundary layer interaction. J. Hydrometeor., 12, 766-786, doi:10.1175/ JHM-D-10-05014.1.

Schoen, J. M., and W. S. Ashley, 2011: A climatology of fatal convective wind events by storm time. Wea. Forecasting, 26, 109-121, doi:10.1175/2010WAF2222428.1.

Tawfik, A. B., and P. A. Dirmeyer, 2014: A process-based framework for quantifying the atmospheric preconditioning of surface-triggered convection. Geophys. Res. Lett., 41, 173-178, doi:10.1002/2013GL057984

Taylor, C. M., and R. J. Ellis, 2006: Satellite detection of soil moisture impacts on convection at the mesoscale. Geophys. Res. Lett., 33, L03404, doi:10.1029/2005GL025252.

_ D. J. Parker, and P. P. Harris, 2007: An observational case study of mesoscale atmospheric circulations induced by soil moisture. Geophys. Res. Lett., 34, L15801, doi:10.1029/ 2007GL030572.

— , R. A. De Jeu, F. Guichard, P. P. Harris, and W. A. Dorigo, 2012: Afternoon rain more likely over drier soils. Nature, $\mathbf{4 8 9}$, 423-426, doi:10.1038/nature11377.

Van Den Broeke, M. S., J. M. Straka, and E. N. Rasmussen, 2008: Polarimetric radar observations at low levels during tornado life cycles in a small sample of classic southern plains supercells. J. Appl. Meteor. Climatol., 47, 1232-1247, doi:10.1175/ 2007JAMC1714.1.

Wang, W., and A. Kumar, 1998: A GCM assessment of atmospheric seasonal predictability association with soil moisture anomalies over North America. J. Geophys. Res., 103, $28637-$ 28 646, doi:10.1029/1998JD200010.

Wei, J., and P. A. Dirmeyer, 2012: Dissecting soil moistureprecipitation coupling. Geophys. Res. Lett., 39, L19711, doi:10.1029/2012GL053038.

Wu, Y., and S. Raman, 1998: The summertime Great Plains low level jet and the effect of its origin on moisture transport. Bound.-Layer Meteor., 88, 445-466, doi:10.1023/ A:1001518302649. 